\title{
Cardiology Rehabilitation wards: Isolation of Staphylococcus capitis. A risk of infection to be kept under control
}

\author{
Pasqualina Laganàa, Santi Deliaa, Maria Anna Conigliob \\ a Department of Biomedical and Dental Sciences and Morphofunctional Imaging, University of Messina, Italy \\ ${ }^{b}$ Department of Medical, Surgical Sciences and Advanced Technologies "G.F. Ingrassia", University of Catania, Italy
}

\section{ARTICLE INFO}

Article history:

Received: 2. 7. 2017

Received in revised form: 12. 2. 2018

Accepted: 15. 2. 2018

Available online: 13. 3. 2018

Klíčová slova:

Endokarditida

Mitrální paravalvulární leak

Perforace posteriorní mitrální

chlopně

Staphylococcus capitis

Keywords:

Endocarditis

Mitral paravalvular leak

Perforation of posterior mitral flap

Staphylococcus capitis

\section{SOUHRN}

Oddělení kardiovaskulární rehabilitace se specializují na rehabilitaci nemocných po kardiochirurgickém výkonu nebo po akutním infarktu myokardu. Nemocniční infekce jsou velmi častou a závažnou komplikací prováděné léčby. $V$ posledních dvou desetiletích se nicméně ukázalo, že hlavní prríčinou prípadů infekce a sepse na jednotkách kardiologické péče jsou koaguláza-negativní stafylokoky (CoNS), mezi nimiž významné místo zaujímá bakterie Staphylococcus capitis. Popisujeme naše zkušenosti z izoláty S. capitis od pacienta, který byl hospitalizován s kardiovaskulárním onemocněním a s bércovými vředy.

(c) 2019, ČKS.

\section{ABSTRACT}

Cardiology Rehabilitation wards specialize in the rehabilitation of patients who are suffering from cardiac surgery or an acute heart attack. Hospital infections are the most frequent and severe complication of healthcare. Nevertheless, during the last two decades, coagulase-negative staphylococci (CoNS) have been indicated as the primary cause of infections and septicemia in cardiology care units. Among the CoNS, the role played by Staphylococcus capitis in the field of infectious processes has been considered. We present our experience of $S$. capitis isolations from a patient admitted with cardiovascular disease with lower limbal diabetic ulcers.

\section{Introduction}

Cardiology Rehabilitation wards specialize in the rehabilitation of patients who are suffering from cardiac surgery or an acute heart attack (such as myocardial infarction). Along with pharmacological treatment, however, always necessary, the rehabilitative aim is to give the patient a life-threatening affective, working, social, as normal condition as possible, compatible with his or her impairment. By combining prescription of physical activity with the modification of the risk profile of patients, this type of rehabilitation is ultimately intended to promote clinical stability, reduce the risk of subsequent cardiovascular events and cardiopathic disabilities. ${ }^{1}$ Often in these wards there are hospitalized elderly patients who, in addition to having cardiologic rehabilitation problems, they are also suffering from concomitant diseases, such as diabetes, venous insufficiency, vascular diseases, circulation disorders and they may have ulcerations related to these pathologies. Particular attention should be paid to these potentially infected ulcers to contain the spread of nosocomial infections in these high-risk units. Hospital infections are the most frequent and severe complication of healthcare. From an etiological point of view there are significant changes in the infections that could result in endocarditis: in addition to classic pathogens often exigent Gram-negative bacteria and fungi were isolated. ${ }^{2}$ Moreover, there are studies reporting cases of endocarditis caused by Acinetobacter baumannii, Salmonella enterica, CoxieIla burnetii, Chlamydia, Legionella, Brucella, Aspergillus, as the responsible of endocarditis..$^{3-8}$ Nevertheless, during the last two decades, coagulase-negative staphylococci (CoNS) have indicated as the primary cause of infections and septicemia in cardiology care units. Among the CoNS, the role played by Staphylococcus capitis in the field of infectious processes has been considered. As reported in 




Fig. 1 - (A) Sampling performed with sterile swab on a diabetic ulcer. (B) Transthoracic echocardiography, section apical 4-chamber, showing perforation of the posterior flap and mitral paravalvular leak.

many articles in the scientific literature we would like to emphasize as $S$. capitis may be potentially related to endocarditis when it is found in the hospital and, in particular, in Cardiology, Cardio-surgery and correlated wards, as Cardiology Rehabilitation. ${ }^{9-11}$ The pathogenicity of the S. capitis strains isolated from patient was measured by evaluating antibiotic resistance factors (Table 1), ability to produce biofilms and survival on materials of various nature (data no showed).

\section{Case presentation}

We present our experience of one case of lethal endocarditis. The patient was a female of 72 years who underwent to cardiac surgery for severity stenosis. The patient's medical history revealed systemic arterial hyper- tension, rheumatic disease in infancy, psoriasis, diabetes and episodes of atrial fibrillation in treatment with oral anticoagulant therapy. ${ }^{12-16}$ There were diabetic ulcers in the lower limbs, apparently not infected (Fig. 1A). She was subjected to a substitution of the mitral valve with a biologic prosthesis. The entire procedure was long but successful. After a week she was assigned to Cardiology Rehabilitation ward and after a few days, for persistent low-grade fever, a broad-spectrum antibiotic treatment is performed. After another 2 days the fever becomes high and persistent. The following night the pulmonary dyspnea evolves with pulmonary edema. The patient is treated with high dose nitroderivatives and diuretics. They quickly developed acute respiratory failure with clinical picture of septic shock and were transferred to the intensive care unit. The echocardiographic evaluation showed a involvement of the mitral valve with perforation of the

\begin{tabular}{|c|c|c|c|}
\hline Sensitive (S) & Intermediately resistant (I) & \multicolumn{2}{|c|}{ Resistant (R) } \\
\hline Amikacin $(\mathrm{AK}, 30 \mu \mathrm{g})$ & Cefalexin $(\mathrm{CL}, 30 \mu \mathrm{g})$ & Amoxicillin (AML, $10 \mu \mathrm{g})$ & Fosfomycin (FOS, $50 \mu \mathrm{g})$ \\
\hline Doxycycline (DXT, $30 \mu \mathrm{g})$ & Erithromycin $(E, 15 \mu g)$ & Ampicillin (AMP, $10 \mu \mathrm{g})$ & 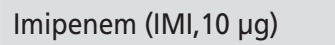 \\
\hline Minocycline $(\mathrm{MH}, 30 \mu \mathrm{g})$ & & $\begin{array}{l}\text { Amoxicillin + clavulanic acid } \\
\text { (AUG, } 20 \mu \mathrm{g}+10 \mu \mathrm{g})\end{array}$ & Levofloxacin (LEV, $5 \mu \mathrm{g}$ ) \\
\hline \multirow[t]{11}{*}{ Vancomycin (VAN, $5 \mu \mathrm{g}$ ) } & & Carbenicillin (CAR, $100 \mu \mathrm{g})$ & Josamycin (JOS, $30 \mu \mathrm{g})$ \\
\hline & & Cefalotin $(K F, 30 \mu g)$ & Methicillin (MET, $5 \mu \mathrm{g}$ ) \\
\hline & & Cefazolin $(K Z, 30 \mu g)$ & Mezlocillin (MEZ, $75 \mu \mathrm{g})$ \\
\hline & & Cefotaxime $(\mathrm{CTX}, 30 \mu \mathrm{g})$ & Nitrofurantoin $(F, 300 \mu g)$ \\
\hline & & Ceftriaxone (CRO, $30 \mu \mathrm{g})$ & Norfloxacin $(\mathrm{NOR}, 10 \mu \mathrm{g})$ \\
\hline & & Cefuroxime $(\mathrm{CXM}, 30 \mu \mathrm{g})$ & Ofloxacin (OFX, $5 \mu \mathrm{g}$ ) \\
\hline & & Cinoxacin $(\mathrm{CIN}, 100 \mu \mathrm{g})$ & Oxacillin $(O X, 5 \mu g)$ \\
\hline & & Ciprofloxacin (CIP, $5 \mu \mathrm{g})$ & Penicillin (P, 10 UI) \\
\hline & & Clindamycin (CD, $10 \mu \mathrm{g})$ & Piperacillin (PRL, $100 \mu \mathrm{g})$ \\
\hline & & Chloramphenicol $(C, 30 \mu \mathrm{g})$ & Rifampicin (RD, $30 \mu \mathrm{g})$ \\
\hline & & Enoxacin $($ ENX, $10 \mu \mathrm{g})$ & Tetracycline $(\mathrm{TE}, 30 \mu \mathrm{g})$ \\
\hline
\end{tabular}

The diameter of the zone of inhibition around each disk was measured with a precision caliper (Mitutoyo, Andover, UK). The strain tested was classified as Resistant (R), Intermediately resistant (I) or Sensitive (S) according to the breakpoints established by Clinical Laboratory Standards Institute (CLSI, 2006). 
posterior flap and mitral paravalvular leak (Fig. 1B). The patient is carried to cardiac surgery for an operation but died in post-surgery for a septicemia. The time of onset of symptoms correlates with the incubation period, also, the culture positive blood for S. capitis, confirms the diagnosis of septicemia. The final diagnosis was sudden cardiac death from infective endocarditis sustained by S. capitis. The relevance of this case is focused on the fact that IE sustained by the $S$. capitis is not a frequent but always a possible cause of sudden death in patients undergoing cardiac surgery, especially for prosthesis implantation. Attention should be paid to the asepsis procedures of the operating room and of equipment.

\section{Discussion}

Hospital germs compared to those circulating in the community show a surely greater resistance to the molecules that we could use to fight them.

Most infections are caused by germs isolated from the environment (water, surfaces, air conditioning systems). As known, for example, Legionella is able to survive for long periods in water and even to replicate in the presence of chlorine, if it manages to create suitable conditions (biofilm, parasitism of amoebas and protozoic cysts, etc.). In this case, a shower or, though less likely, simple hand washing could expose a debilitated subject to contact with the germ and then get sick. 17-20 The surfaces of a hospital environment are a potential source of contamination, considering that the germs can adhere to it; the adhesion is conditioned by the type of material that constitutes the surface and degree of detergency. Often they are the same hands as health workers who can unknowingly become a vehicle of infection [21]. The importance of this alert highlight that infections sustained by environmental germs is frequent and a possible cause of sudden death in cardiopathic patients. Moreover, an efficient monitoring of surfaces, combined with air and water sampling is beneficial for preventing infections. Attention should be given in increasing environmental surveillance in higher risk areas, otherwise you could apply to new methods of estimation of the spread of germs, such as Geostatistics [22]. For these reasons, we hope that our message serves to give greater attention to the problem and increases the environmental surveillance.

\section{Conflict of interest \\ None}

\section{Funding body}

None.

\section{Ethical statement}

Authors state that the research was conducted according to ethical standard.

\section{Informed consent}

Informed consent was obtained from the patient.

\section{References}

1. Staněk V, Gebauerová M, Pitha J, et al. The risk profile of patients with acute coronary syndrome treated at IKEM between 2006 and 2013. Cor Vasa 2017;59:e119-e127.

2. Prendergast $B D$. The changing face of infective endocarditis. Heart 2006;92:879-885.

3. Laganà $\mathrm{P}$, Melcarne L, Delia S. Acinetobacter baumannii and endocarditis, rare complication but important clinical relevance. Int J Cardiol 2015;187:678-679.

4. Laganà $P$, Delia $S$, Dattilo $G$, et al. A case of Infective Endocarditis due to $S$. enterica phagetype 35 . First report. Clin Ter 2017;6:e397-e400.

5. Laganà $P$, Delia $S$, Avventuroso $E$, et al. Risk assessment of legionellosis in cardiology units. J Prev Med Hyg 2017;58:E173-E176.

6. Guyot S, Goy JJ, Gersbach P, et al. L. pneumophila aortitis in a heart transplant recipient. Transpl Infect Dis 2007;9:58-59.

7. Alici $\mathrm{H}$, Ercan S, Davutoglu V. Brucella infective endocarditis. Cor Vasa 2014;56:e433-e435.

8. Godava J, Krejčí J, Hude P, et al. Invasive aspergillosis following the heart transplantation - A case report. Cor Vasa 2016;58:e509-e512.

9. Lina B, Celard M, Vandenesch $F$, et al. Infective endocarditis due to Staphylococcus capitis. Clin Infect Dis 1992;15:173174.

10. Takano T, Ohtsu Y, Terasaki T, et al. Prosthetic valve endocarditis caused by Staphylococcus capitis: report of 4 cases. J Cardiothorac Surg 2011;6:131.

11. Terada Y, Mitsui T, Enomoto Y. Prosthetic valve endocarditis caused by Staphylococcus capitis. Ann Thorac Surg 1996;62:324.

12. Imbalzano E, Casale M, D'Angelo M, et al. Cardiovascular risk and psoriasis: a role in clinical cardiology? Angiology 2015;66:101-103.

13. Dattilo G, Imbalzano G, Casale $M$, et al. Psoriasis and Cardiovascular Risk: Correlation Between Psoriasis and Cardiovascular Functional Indices. Angiology 2018;69:31-37.

14. Dattilo G, Imbalzano E, Lamari A, et al. Ischemic heart disease and early diagnosis. Study on the predictive value of 2D strain. Int J Cardiol 2016;215:150-156.

15. Imbalzano E, Di Bella G, Lamari A, et al. Right ventricular myocardial deformation in young healthy subjects: A comparison study between 2D Strain and traditional parameters. J Exp Clin Cardiol 2014;20:2729-2743.

16. Dattilo G, Falanga $G$, Casale M, et al. Oral Anticoagulants: Old and New Therapy In: Berhardt LV, et al., editors. Advances in Medicine and Biology. New York: Nova Science Publishers, 2015:13-71.

17. Laganà $\mathrm{P}$, Caruso $\mathrm{G}$, Piccione $\mathrm{D}$, et al. Legionella spp., amoebae and not-fermenting Gram negative bacteria in an Italian university hospital water system. Ann Agric Environ Med 2014;21:489-493.

18. Montagna MT, De Giglio O, Napoli C, et al. Legionella spp. contamination in indoor air: preliminary results of an Italian multicenter study. Epidemiol Prev 2014;38(Suppl 2):62-65.

19. Montagna MT, Cristina ML, De Giglio O, et al. Serological and molecular identification of Legionella spp. in water and surrounding air samples in Italian healthcare facilities. Environ Res 2016;146:47-50.

20. Montagna MT, De Giglio O, Cristina ML, et al. Evaluation of Legionella air contamination in healthcare facilities by different sampling methods: an Italian multi center study. Int J Environ Res Public Health 2017;14(7). pii: E670. doi: 10.3390/ijerph14070670.

21. Stilo A, Troiano G, Melcarne L, et al. Hand washing in operating room: a procedural comparison. Epidemiology Biostatistics and Public Health 2016;13:e11734-1-e11734-7.

22. Laganà $P$, Moscato $U$, Poscia $A$, et al. The Geostatistics, tool applied to the distribution of Legionella pneumophila in a hospital water system. Ann Agric Environ Med 2015;22:655-660. 